\title{
THE PERCEPTIONS OF PRIMARY EDUCATION TEACHERS ABOUT INCLUSIVE EDUCATION IN THE GREEK EDUCATIONAL SYSTEM
}

\author{
Vasileiadis Ilias ${ }^{1 i}$, \\ Koutras Spyros ${ }^{2}$, \\ Dimitriadou Ioanna ${ }^{3}$ \\ ${ }^{1}$ Department of Primary Education \\ University of Thessaly, \\ Argonafton \& Filellinon, \\ 38221 Volos, Greece \\ ${ }^{2}$ Queen Margaret University, \\ Edinburgh, UK \\ ${ }^{3}$ Univesity of Macedonia, \\ Thessaloniki, Greece
}

\begin{abstract}
:
Teachers' attitudes towards inclusive education of typically developing and nontypically developing students are a key factor for effective school psychological support, smooth attendance of all students and seamless operation of the classroom. The purpose of the present study was to investigate the views of primary education teachers in schools of Northern Greece regarding the factors that shape their attitudes and influence their participation in promoting the joint education of disabled and non-disabled students. The research sample consisted of 48 primary school teachers in the area. The Teacher Attitudes Toward Inclusion Scale (TATIS) questionnaire was adapted and administered. The results of the study show that teachers who have been involved in inclusive education processes in the past and evaluate their participation as positive for themselves and their students, develop and establish more positive attitudes regarding the usefulness of inclusive education programmes compared to teachers who either have no positive experiences from participating in the education of students with disabilities in the general classroom or have never taught non-typically developing students. In conclusion, the organised and methodologically envisaged development of inclusive education increases the efficiency of teachers and promotes a positive learning climate in the classroom.
\end{abstract}

Keywords: inclusive education, teachers' attitudes, development of positive attitudes

i Correspondence: email ilvasileiadis@uth.gr 


\section{Introduction}

Inclusive education is currently considered as the most appropriate form of education and is a key priority in most countries in the Western world, including Greece. Research has focused on the social and emotional benefits of inclusive education, which result from the interaction of children with their typically developing peers (Avramidis, 2010).

The study of teachers' attitudes, perceptions and readiness regarding inclusive education in general schools has been a subject of continuous research worldwide. Teachers' attitudes are the ones that can promote, but also hinder, the inclusion of students with disabilities (Lifshitz, Glaubman \& Issawi, 2004). The severity of the disability is a determining factor for the degree of acceptance of a student in the classroom (De Boer, Pijl, \& Minnaert, 2011), while stereotypes play a key role in teachers' attitudes and perceptions. For each type of disability, specific stereotypes are developed that affect the educational capabilities of each disabled student and determine the attitude that both teachers and their peers will develop towards them. Consequently, with regard to students with disabilities who attend general schools, where teachers foster acceptance and respect for diversity, more positive attitudes are developed by their peers and teachers compared to other students with disabilities who do not attend a school with a similar climate (De Laat, Freriksen \& Vervloed, 2013).

\section{Literature Review}

Teachers' attitudes and perceptions regarding inclusive education of typically developing and non-typically developing students in general schools differ considerably, not only in relation to social prejudice but also to the general structural difficulties of the education system to effectively assist students with disabilities and to the inadequate teacher training. In this respect, it is recognized that special education teachers are more suitable to deal with and educate children with disabilities, which is inextricably linked to the quality of cooperation between special and general education teachers in the school context (Avramidis \& Norwich, 2002).

Teachers are generally aware of the advantages of non-segregation, while they respect children's right to education. In practical terms, teachers who experience inclusive education develop a different attitude. Newly appointed teachers, citing lack of experience, show no confidence in teaching students with disabilities, which negatively affects their intentions and behavior towards these students (De Boer, Pijl \& Minnaert, 2011), and appear reluctant to engage in coexistence interventions of children with and without disabilities (Waldron, McLeskey \& Pacchiano, 1999). On the other hand, teachers with several years of experience are equally skeptical, compared to their colleagues with fewer years of service, regarding the education of students with special educational needs in the general school (Avramidis, Bayliss, \& Burden, 2000). This attitude is related to the quality of previous experience with students with disabilities. Teachers who, prior to the implementation of inclusion programs, have positive experiences from inclusive 
education of students with and without disabilities, are positive to participate actively in interventions concerning students with disabilities in the future. On the contrary, in cases where their experiences (personal or professional) are negative, they do not appear willing to adopt changes and participate in innovative programs (Vasileiadis \& DoikouAvlidou, 2018). In addition, teachers with many years of service put forward their lack of knowledge when they are negative about the inclusive education of students with educational difficulties (Waldron, McLeskey, \& Pacchiano, 1999). Therefore, teachers, irrespective of years of service, are particularly skeptical in practice regarding their active involvement in the inclusive education of students with disabilities in the general school (De Boer, Pijl, \& Minnaert, 2011).

Research findings on teachers' views about inclusive education of students with special educational needs and the promotion of coexistence programs suggest that they consider that: (a) there is little scope for modification of the daily schedule; (b) typically developing students do not benefit significantly in any area; (c) students with disabilities do not develop further cognitive and professional skills after the implementation of the interventions; (d) teachers themselves are not responsible for promoting inclusion programs; (e) inclusion is not possible for all students with disabilities; (f) special schools offer specialized services to students and parents; and (g) students with disabilities cannot do it alone on a social and emotional level and need the help of their families and experts (Kalyva, Gojkovic \& Tsakiris, 2007).

In view of the above, it can be explained why many teachers, although theoretically in favor of inclusive education, believe that it is better for students with disabilities to attend special classes or schools. For many teachers, the promotion of inclusive education processes is not their responsibility but lies with the expertise of special education teachers and psychologists (Batsiou, Bebetsos, Panteli \& Antoniou, 2008). Thus, when they are invited to participate in inclusive education interventions, their contribution is reflected in terms of morality and humanity, as they consider that the cognitive benefits will not be significant for any student, and point out the fact that the responsibility for the intervention lies with an out-of-school factor (such as the Ministry of Education) (Zoniou-Sideri \& Vlachou, 2006).

\section{Material and Methods}

\subsection{Aims of the Study}

The study aims to explore the views of primary education teachers on:

1. The advantages and disadvantages of inclusive education.

2. The potential of students with disabilities to be included in the general classroom.

3. The quality of the training offered to primary education teachers for the implementation of inclusive education programs.

4. The differentiation of their perceptions about the development of inclusive education programs depending on their years of service, training and teaching experience with students with disabilities. 


\subsection{Research Hypotheses}

Following the literature review and the establishment of the research objectives, the following research hypotheses have emerged:

1) Primary education teachers with more years of service feel more positively about the philosophy of inclusive education compared to their colleagues with fewer years of service.

2) Primary education teachers with special education training will have a more positive attitude towards inclusive education than primary education teachers without similar training.

3) Primary school teachers who have experience in teaching students with disabilities will be more positive to the development of inclusive education programs than primary school teachers who have not taught students with disabilities.

\subsection{Research Sample}

The selection of the sample was based on the highest possible representation of the population and for this reason stratified sampling was used. For the purposes of this study, schools from the prefecture of Thessaloniki were selected on the basis of their location, the financial background of the area they are located in and their distance from the city center. More specifically, the research sample consisted of 48 primary school teachers in the area. It was not possible to have a larger sample for conducting the research since the school units which students with disabilities attend are not many. With regard to the gender of the teachers involved (see Table 1), there was a greater participation of female compared to male teachers, which is expected as in primary education there is a similar distribution of women and men (Papadopoulou, Kokaridas, Papanikolaou \& Patsiaouras, 2004).

Table 1: Distribution of research subjects by gender

\begin{tabular}{|l|c|c|}
\hline Gender & Frequency & Relative frequency (\%) \\
\hline Male & 18 & 37.5 \\
\hline Female & 30 & 62.5 \\
\hline
\end{tabular}

Regarding age, we see that the majority of teachers who participated in the present research study were over 43 years old, while in the other age categories the distribution is divided. The fact that older ages prevail is to be expected as there has not been a large number of teacher appointments in recent years in the Greek education system. At the same time, the age distribution is expected to affect the distribution of teachers by years of service. The distribution is presented in Table 2 . 
Table 2: Distribution of research subjects by years of service

\begin{tabular}{|l|c|c|}
\hline Years of service & Frequency & Relative frequency (\%) \\
\hline Up to 4 & 7 & 14.6 \\
\hline $5-9$ & 10 & 20.8 \\
\hline $10-14$ & 10 & 20.8 \\
\hline 15 or more & 21 & 43.8 \\
\hline
\end{tabular}

Of particular interest is Table 3, which follows and presents the teachers' work experience in special and general education. Three categories were created comprising the teachers who have taught mainly in general education, mainly in special education or in both types of education. According to the table, $81 \%$ of teachers say they have little experience in teaching people with disabilities, while $19 \%$ have taught people with disabilities for at least five school years. It is noteworthy that only $6.3 \%$ of them have taught exclusively in special education, while $12.5 \%$ have taught in both types of education, which means that they may have managed an inclusion program in the general school setting.

Table 3: Distribution of research subjects by type of service

\begin{tabular}{|l|c|c|}
\hline Type of service & Frequency & Relative frequency (\%) \\
\hline General education & 39 & 81.3 \\
\hline Special education & 3 & 6.3 \\
\hline General and special education & 6 & 12.5 \\
\hline
\end{tabular}

Finally, the distribution of teachers as to whether they have followed some form of training for the teaching of people with disabilities is also presented (Table 4). It is noted that only 1 out of 4 teachers have received training in disability issues.

Table 4: Distribution of research subjects

based on whether they have completed a training program

\begin{tabular}{|l|c|c|}
\hline Training & Frequency & Relative frequency (\%) \\
\hline Yes & 11 & 22.9 \\
\hline
\end{tabular}

\subsection{Research Instruments}

In order to collect the research data, a demographic survey questionnaire was used which consisted of clear and short questions about the respondent in conjunction with the Teacher Attitudes Toward Inclusion Scale (TATIS) questionnaire (Cullen, Gregory \& Noto, 2010).

In the demographic questionnaire developed, the demographic and professional characteristics of the participants were collected, such as age, gender, special education training, experience with people with disabilities, etc. These factors are important since, as stated in the literature review, they influence teachers' attitudes towards inclusive education.

The TATIS questionnaire is a well-structured and well-tested questionnaire of teachers' attitudes towards inclusive education which was developed by Cullen, Gregory and Noto (2010) aiming at exploring the views of teachers in key areas of inclusive 
education, such as the usefulness of previous service and training as well as their readiness to implement inclusive education programs. From the different variants of the questionnaire, 14 questions were selected and translated. These were the ones considered to cover the topics of the present study and have been divided into categories for better analysis and presentation of the results.

The questionnaire included a seven-point response scale (0 to 6) where number 0 corresponded to the option Disagree Very Strongly and number 6 to the option Agree Very Strongly, with number 3 being the neutral option Neither agree nor disagree. The questionnaire was translated and adapted to Greek following a double translation. The results were analyzed using the factor analysis technique from which the three individual factors of the questionnaire were identified with regard to teachers' attitudes towards inclusive education. The three factors that emerged were: (a) adequacy of knowledge for the implementation of inclusive education; (b) teachers' personal view on the joint education of all students; (c) pros and cons of inclusive education.

The reliability of the administered instrument was confirmed through the Cronbach's alpha correlation procedure, the result of which was 0.844 and can therefore be considered sufficiently reliable.

\subsection{Research Procedure}

The administration process lasted three months from April to June 2019. The questionnaires were distributed to the teachers following a visit to the schools and after contacting the principal of each school. The only exception was the school in the rural area where, after communication and consultation with the school principal, questionnaires were sent in electronic form and given to teachers by the principal himself. Then, after they were successfully completed, they were returned in the same way by the school principal. To avoid errors, throughout the process instructions and clarifications were provided over the phone.

Fifty-one questionnaires were administered to teachers and 48 of them were returned completed. Two of the teachers who did not participate stated that it was not possible for them to participate due to workload, while one teacher was not able to complete the questionnaire due to illness. In order to carry out the survey properly, it was deemed necessary to ask permission from the schools in which the interviewed teachers work. In addition, the necessary clarifications about the purpose of the study as well as the research plan were provided, while the participants were assured that they would be informed about the results of the study.

In the final stage and following the collection of the questionnaires, the results were analyzed using the SPSS 21 statistical analysis software and compared to the existing literature. The outcome of this process is presented below. 


\section{Results}

\subsection{Frequency of contact between teachers and people with disabilities}

The questions about how often teachers have contact with people with disabilities revealed the following information. It was observed that only one in four teachers has frequent contact with people with disabilities (at least on a weekly basis) outside the school environment. On the contrary, 2 out of 3 teachers, that is $63 \%$ of them, stated that they rarely come in contact with people with disabilities (see Table 5).

Table 5: Frequency of contact between teachers and people with disabilities

\begin{tabular}{|l|c|c|}
\hline Contact & Frequency & Relative frequency (\%) \\
\hline Daily & 7 & 14.6 \\
\hline Weekly & 4 & 8.3 \\
\hline Monthly & 7 & 14.6 \\
\hline Rarely & 30 & 62.5 \\
\hline
\end{tabular}

In a similar question about the existence of family members with any form of disability, the following emerged. The absence of people with disabilities in the immediate family environment is in line with the results of the above table on the frequency of contact with people with disabilities, since the six people who have a person with a disability in their family are expected to come in contact with this person on a daily basis (see Table 6).

Table 6: Frequency of contact between

teachers and people with disabilities in the family

\begin{tabular}{|l|c|c|}
\hline Family & Frequency & Relative frequency (\%) \\
\hline Yes & 6 & 12.5 \\
\hline No & 42 & 87.5 \\
\hline
\end{tabular}

\subsection{Teachers' views about people with disabilities}

The following table (Table 7) presents in detail the standard deviation and mean value for each of the 14 items of the TATIS questionnaire to which the teachers declared their degree of agreement. The higher the mean value, the more favorable the attitude the respondents expressed towards the particular item.

After examining the table, it is observed that the two highest values appear in questions 13 'The curriculum needs to be reformed in order for the inclusive education model to be implemented' and 5 'Schools are not properly prepared to accept students with disabilities' with 4.00 and 3.88 respectively. Our data show that all respondents agree that school in its current form is not properly prepared for implementing an inclusive education project.

The two lowest values appear in questions 2 'I think I am ready to teach a student with a disability' and 12 'Training of teachers in special education issues should become mandatory' with 1.98 each. The results reveal a lack of confidence among teachers in terms 
of their preparation, while most of them do not think that training should be mandatory. We see a tendency to avoid responsibility as teachers are not ready and particularly willing to be properly prepared in order to carry out inclusive education projects.

Table 7: Mean values and standard deviations in the TATIS questionnaire items

\begin{tabular}{|l|c|c|}
\hline Question & Mean & Standard deviation \\
\hline $\begin{array}{l}\text { 1. All children with disabilities should be educated in the general } \\
\text { classroom along with others. }\end{array}$ & 2.29 & 1.624 \\
\hline 2. I think I am ready to teach a student with a disability. & 1.98 & 1.669 \\
\hline $\begin{array}{l}\text { 3. The inclusion of students with disabilities depends on the degree } \\
\text { of disability. }\end{array}$ & 3.40 & 1.144 \\
\hline $\begin{array}{l}\text { 4. Children with disabilities do not impede the progress of other } \\
\text { students in the general classroom. }\end{array}$ & 3.33 & 1.521 \\
\hline $\begin{array}{l}\text { 5. Schools are not properly prepared to accept students with } \\
\text { disabilities. }\end{array}$ & 3.88 & 1.606 \\
\hline $\begin{array}{l}\text { 6. Children with severe forms of disability should be educated in } \\
\text { general schools. }\end{array}$ & 2.17 & 1.155 \\
\hline 7. I feel anxious when I have to teach a student with a disability. & 3.85 & 1.304 \\
\hline 8. Students with disabilities perform better in general education. & 2.46 & 1.383 \\
\hline $\begin{array}{l}\text { 9. I feel more ready to teach a student with learning difficulties } \\
\text { than a student with a moderate or severe disability. }\end{array}$ & 3.35 & 1.139 \\
\hline 10. Students with disabilities are able to achieve learning outcomes. & 2.48 & 1.384 \\
\hline $\begin{array}{l}\text { 11. Students with disabilities acquire social skills by socializing } \\
\text { with other students. }\end{array}$ & 3.52 & 1.304 \\
\hline $\begin{array}{l}\text { 12. Training of teachers in special education issues should become } \\
\text { mandatory. }\end{array}$ & 1.98 & 1.495 \\
\hline $\begin{array}{l}\text { 13. The curriculum needs to be reformed in order for the inclusive } \\
\text { education model to be implemented. }\end{array}$ & 4.00 & 1.288 \\
\hline $\begin{array}{l}\text { 14. The interaction of students with people with disabilities has } \\
\text { positive results for other students too. }\end{array}$ & 3.54 & 1.271 \\
\hline
\end{tabular}

The rest of the questions reveal a negative attitude on behalf of the teachers regarding the competencies of students with disabilities and their potential to be fully included, which is reflected in questions 1, 6, 8, 10: 'All children with disabilities should be educated in the general classroom along with others' (2.29), 'Children with severe forms of disability should be educated in general schools' (2.17), 'Students with disabilities perform better in general education' (2.46) and 'Students with disabilities are able to achieve learning outcomes' (2.46), respectively.

In questions 3, 4, 7, 9, 11 and 14 the respondents were more neutral, with the answers ranging from 3.33 in question 4 'Children with disabilities do not impede the progress of other students in the general classroom' and 3.85 in question 7 'I feel anxious when I have to teach a student with a disability'. Questions 11 'Students with disabilities acquire social skills by socializing with other students' and 14 'The interaction of students with people with disabilities has positive results for other students too' are quite interesting, since they reveal marginally positive attitudes. 
Afterwards, an attempt was made to group the questions so that each group corresponds as closely as possible to one of the purposes of the study. The subcategories which emerged after the factor analysis are shown in Table 8 below.

Table 8: The four subcategories of the TATIS questionnaire

\begin{tabular}{|c|c|}
\hline \multirow{4}{*}{$\begin{array}{l}\text { Benefits of } \\
\text { inclusive } \\
\text { education }\end{array}$} & $\begin{array}{l}\text { 4. Children with disabilities do not impede the progress of other students in the } \\
\text { general classroom. }\end{array}$ \\
\hline & 8. Students with disabilities perform better in general education. \\
\hline & $\begin{array}{l}\text { 11. Students with disabilities acquire social skills by socializing with other } \\
\text { students. }\end{array}$ \\
\hline & $\begin{array}{l}\text { 14. The interaction of students with people with disabilities has positive results } \\
\text { for other students too. }\end{array}$ \\
\hline \multirow{3}{*}{$\begin{array}{l}\text { Educational } \\
\text { material and } \\
\text { infrastructure }\end{array}$} & 5. Schools are not properly prepared to accept students with disabilities. \\
\hline & 12. Training of teachers in special education issues should become mandatory. \\
\hline & $\begin{array}{l}\text { 13. The curriculum needs to be reformed in order for the inclusive education } \\
\text { model to be implemented. }\end{array}$ \\
\hline \multirow{3}{*}{$\begin{array}{l}\text { Teachers' } \\
\text { competence and } \\
\text { readiness }\end{array}$} & 2. I think I am ready to teach a student with a disability. \\
\hline & 7. I feel anxious when I have to teach a student with a disability. \\
\hline & $\begin{array}{l}\text { 9. I feel more ready to teach a student with learning difficulties than a student } \\
\text { with a moderate or severe disability. }\end{array}$ \\
\hline \multirow{4}{*}{$\begin{array}{l}\text { Potential of } \\
\text { students to be } \\
\text { included }\end{array}$} & $\begin{array}{l}\text { 1. All children with disabilities should be educated in the general classroom } \\
\text { along with others. }\end{array}$ \\
\hline & 3. The inclusion of students with disabilities depends on the degree of disability \\
\hline & $\begin{array}{l}\text { 6. Children with severe forms of disability should be educated in general } \\
\text { schools. }\end{array}$ \\
\hline & 10. Students with disabilities are able to achieve learning outcomes. \\
\hline
\end{tabular}

The resulting grouped mean values are presented in Table 9 and Figure 1.

Table 9: Mean values and standard deviations of the four subcategories of the TATIS questionnaire

\begin{tabular}{|l|c|c|}
\hline Category & Mean & Standard deviation \\
\hline Benefits of inclusive education & 12.19 & 2.703 \\
\hline Educational material and infrastructure & 9.19 & 1.409 \\
\hline Teachers' competence and readiness & 8.10 & 1.938 \\
\hline Potential of students to be included & 12.00 & 2.626 \\
\hline
\end{tabular}

With regard to the benefits and advantages of inclusive education, teachers are fairly positive towards the whole idea, which is demonstrated by a mean value of 12.19 . Teachers appear to be more skeptical regarding both the material and procedures and their readiness to teach students with disabilities. Finally, opinions are divided on the potential of all students to be included, where the mean value is 12 and the standard deviation is quite high. 


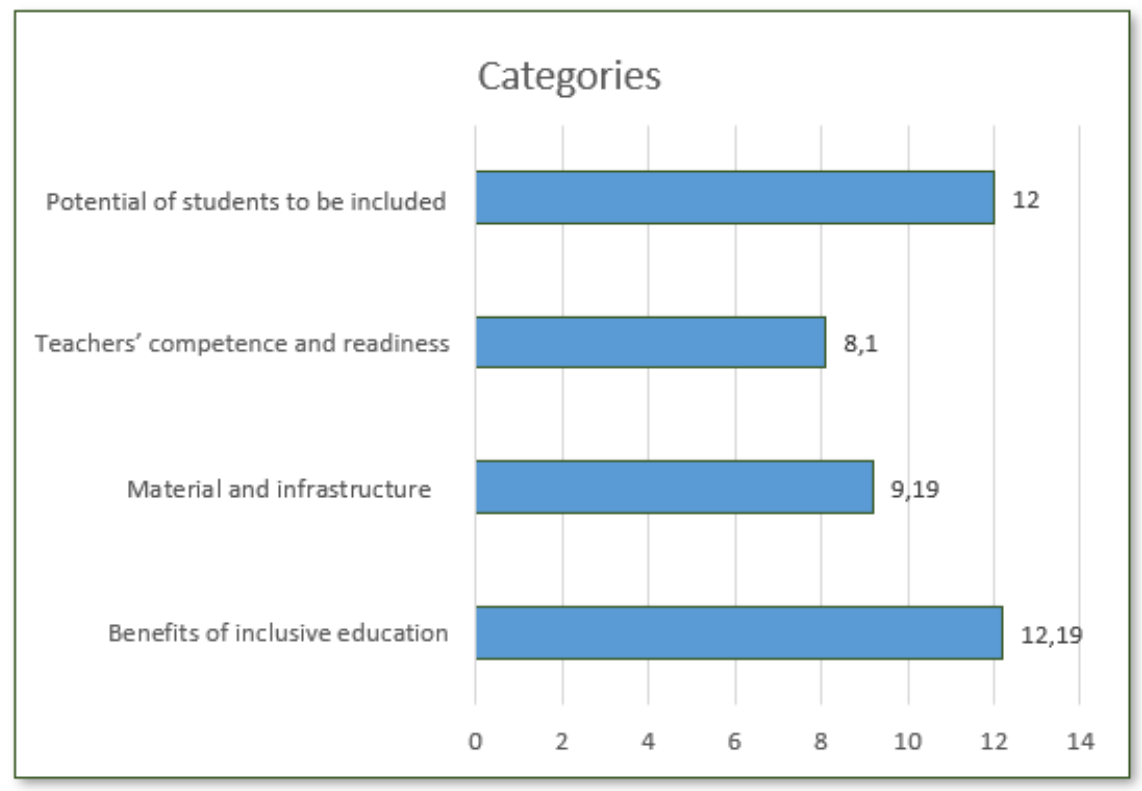

Figure 1: Mean values of the four subcategories of the TATIS questionnaire

\subsubsection{Connection between years of service and views on inclusive education (1st research hypothesis)}

According to the first research hypothesis, teachers with more years of work experience are more positive towards inclusive education and more receptive to its implementation compared to their colleagues with fewer years of service. Greater contact between teachers and people with disabilities creates a greater sense of confidence and has a positive influence on teachers' attitude.

Table 10: Mean values and standard

deviations of the TATIS questionnaire by age group

\begin{tabular}{|l|c|c|c|}
\hline Years of service & N & Mean & Standard deviation \\
\hline Up to 4 & 7 & 43.57 & 3.60 \\
\hline $5-9$ & 10 & 43.70 & 5.98 \\
\hline $10-14$ & 10 & 39.80 & 5.07 \\
\hline 15 or more & 21 & 40.52 & 4.24 \\
\hline
\end{tabular}

The mean values and standard deviations of the TATIS questionnaire by age group (see Table 10) does not confirm the first hypothesis, given that the first two age groups have a higher mean value in the questionnaire score which indicates greater degree of receptiveness to inclusive education. In addition, after testing the significance of the finding, the p-value that was found was 0.146 which is greater than $5 \%$, and this confirms that our finding is not statistically significant. Our first research hypothesis seems to be rejected since it is not statistically obvious that there is a connection between years of service and teachers' attitudes towards inclusive education. The results for each subcategory of the TATIS questionnaire as derived from the ANOVA analysis and testing are presented in detail in Table 11 below. 
Table 11: Mean, standard deviation (SD), F-distribution values and statistical significance level for the interaction between the factors '

subcategories of the TATIS questionnaire' and 'years of service'

\begin{tabular}{|c|c|c|c|c|c|}
\hline & & Mean & Standard deviation & F & Sig. \\
\hline \multirow{5}{*}{$\begin{array}{l}\text { Benefits of } \\
\text { inclusive } \\
\text { education }\end{array}$} & Up to 4 & 13.5714 & 2.50713 & \multirow{5}{*}{2.190} & \multirow{5}{*}{0.103} \\
\hline & $5-9$ & 13.1000 & 2.64365 & & \\
\hline & $10-14$ & 10.7000 & 3.12872 & & \\
\hline & 15 or more & 12.0000 & 2.34521 & & \\
\hline & Total & 12.1875 & 2.70269 & & \\
\hline \multirow{5}{*}{$\begin{array}{l}\text { Teachers' } \\
\text { competence and } \\
\text { readiness }\end{array}$} & Up to 4 & 9.0000 & 1.63299 & \multirow[t]{5}{*}{0.079} & \multirow[t]{5}{*}{0.971} \\
\hline & $5-9$ & 9.1000 & 1.28668 & & \\
\hline & $10-14$ & 9.3000 & 1.49443 & & \\
\hline & 15 or more & 9.2381 & 1.44585 & & \\
\hline & Total & 9.1875 & 1.40903 & & \\
\hline \multirow{5}{*}{$\begin{array}{l}\text { Educational } \\
\text { material and } \\
\text { infrastructure }\end{array}$} & Up to 4 & 8.8571 & 1.34519 & \multirow[t]{5}{*}{0.438} & \multirow[t]{5}{*}{0.727} \\
\hline & $5-9$ & 7.8000 & 2.09762 & & \\
\hline & $10-14$ & 8.1000 & 2.23358 & & \\
\hline & 15 or more & 8.0000 & 1.94936 & & \\
\hline & Total & 8.1042 & 1.93775 & & \\
\hline \multirow{5}{*}{$\begin{array}{l}\text { Potential of } \\
\text { students } \\
\text { to be included }\end{array}$} & Up to 4 & 12.1429 & 2.19306 & \multirow[t]{5}{*}{2.105} & \multirow[t]{5}{*}{0.113} \\
\hline & $5-9$ & 13.7000 & 2.71006 & & \\
\hline & $10-14$ & 11.7000 & 3.23351 & & \\
\hline & 15 or more & 11.2857 & 2.17124 & & \\
\hline & Total & 12.0000 & 2.62557 & & \\
\hline \multirow{5}{*}{ Total Index } & Up to 4 & 43.5714 & 3.59894 & \multirow[t]{5}{*}{1.885} & \multirow[t]{5}{*}{0.146} \\
\hline & $5-9$ & 43.7000 & 5.98238 & & \\
\hline & $10-14$ & 39.8000 & 5.07280 & & \\
\hline & 15 or more & 40.5238 & 4.23815 & & \\
\hline & Total & 41.4792 & 4.87717 & & \\
\hline
\end{tabular}

\subsubsection{Connection between special education training and views on inclusive education} (2nd research hypothesis)

With regard to the effectiveness of training programs, teachers who have attended training programs on disability and inclusion issues were expected to express more positive attitudes towards promoting inclusive education in the Greek education system. Table 12 and Figure 2 present the connection between the participation of teachers in special education trainings and their views on inclusive education.

Table 12: Mean values and standard deviations of the TATIS questionnaire for the variable 'participation in a training program'

\begin{tabular}{|l|c|c|c|}
\hline Training & Number & Mean & Standard deviation \\
\hline Yes & 11 & 45.91 & 3.42 \\
\hline No & 37 & 40.16 & 4.48 \\
\hline
\end{tabular}




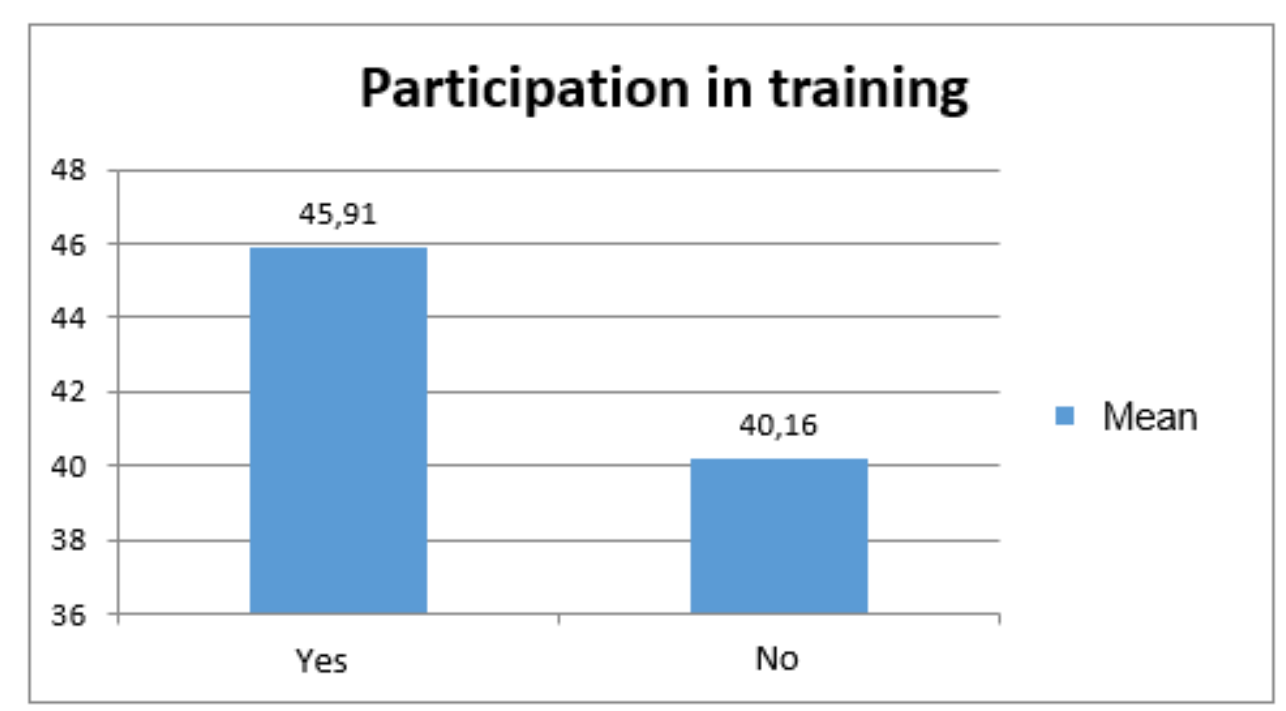

Figure 2: Mean values of the TATIS questionnaire for the variable 'participation in a training program'

The graph shows the 6-point difference in the average value of the total index of positive attitudes towards inclusive education for the teachers who have attended training courses on special education compared to those who have not attended. The test of the significance of the finding in this case proves that our result is statistically significant ( $p=0.0003$ ), as the significance index is less than 0.05 .

It is therefore observed that teachers who have been trained in disability issues have a more positive attitude towards the implementation of inclusive education programs. This result confirms the second research hypothesis. Table 13 presents in detail the mean values, standard deviations, F-distribution values and statistical significance levels for the interaction between the factors 'subcategories of the TATIS questionnaire' and 'special education training'.

Table 13: Mean, standard deviation (SD), F-distribution values and statistical significance level for the interaction between the factors' subcategories of the TATIS questionnaire' and 'special education training'

\begin{tabular}{|c|c|c|c|c|c|}
\hline & & Mean & Standard deviation & $\mathbf{F}$ & Sig. \\
\hline \multirow{3}{*}{$\begin{array}{l}\text { Benefits of } \\
\text { inclusive } \\
\text { education }\end{array}$} & Yes & 14.4545 & 1.9679 & \multirow[t]{3}{*}{12.497} & \multirow[t]{3}{*}{$0.001^{*}$} \\
\hline & No & 11.5135 & 2.5344 & & \\
\hline & Total & 12.1875 & 2.7027 & & \\
\hline \multirow{3}{*}{$\begin{array}{l}\text { Teachers' } \\
\text { competence and } \\
\text { readiness }\end{array}$} & Yes & 8.9091 & 0.7006 & \multirow[t]{3}{*}{0.552} & \multirow[t]{3}{*}{0.461} \\
\hline & No & 9.2703 & 1.5572 & & \\
\hline & Total & 9.1875 & 1.4090 & & \\
\hline \multirow{3}{*}{$\begin{array}{l}\text { Educational } \\
\text { material and } \\
\text { infrastructure }\end{array}$} & Yes & 8.3636 & 1.5015 & \multirow[t]{3}{*}{0.252} & \multirow[t]{3}{*}{0.618} \\
\hline & No & 8.0270 & 2.0614 & & \\
\hline & Total & 8.1042 & 1.9378 & & \\
\hline \multirow{3}{*}{$\begin{array}{l}\text { Potential of } \\
\text { students to be } \\
\text { included }\end{array}$} & Yes & 14.1818 & 2.3160 & \multirow[t]{3}{*}{12.203} & \multirow[t]{3}{*}{$0.001^{*}$} \\
\hline & No & 11.3514 & 2.3713 & & \\
\hline & Total & 12.0000 & 2.6256 & & \\
\hline
\end{tabular}




\begin{tabular}{|l|l|l|l|l|l|}
\hline \hline \multirow{3}{*}{ Total Index } & Yes & 45.9091 & 3.4192 & \multirow{2}{*}{15.373} & \multirow{2}{*}{$0.0003^{*}$} \\
\cline { 2 - 4 } & No & 40.1622 & 4.4753 & & \\
\cline { 2 - 4 } & Total & 41.4792 & 4.8772 & & \\
\hline
\end{tabular}

The analyses show that in two subcategories our result is statistically significant. In the first category which regards the benefits of inclusive education $(p=0.001<0.05)$ there is a statistically significant difference in the mean value of the indices. More specifically, teachers with training have a more positive attitude towards this factor by approximately three points, a fact which strengthens our research hypothesis.

In the fourth subcategory, which refers to the potential of students with disabilities to be included in the general education, we have again a statistically significant result $(p=0.001<0.05)$ which also in this case confirms our research hypothesis. Teachers with special education training have a more positive attitude compared to teachers without training, as a result the mean value of the two categories differs by 2.8 points.

To sum up, the second research hypothesis is statistically confirmed. Teachers with special education training have a more positive attitude towards the implementation of inclusive education programs. The factors which are associated with this result and reinforce the positive attitude towards the development of inclusion programs are the benefits that arise for all participating students and the potential the students have to be included in the general classroom environment.

\subsubsection{Connection between previous teaching experience in inclusive education} programs and the teachers' attitude towards inclusive education (3rd research hypothesis)

According to statistical analyses, teachers who do not have teaching experience in inclusive education appear more skeptical regarding the results of this model of education. Table 14 and Figure 3 show the mean values of the attitudes for the two categories of teachers with experience and with no experience in inclusive education programs.

Table 14: Mean values and standard deviations of the TATIS questionnaire for the variable 'experience in inclusive education'

\begin{tabular}{|l|c|c|c|}
\hline Experience in inclusive education & Number & Mean & Standard deviation \\
\hline Yes & 9 & 46.56 & 3.78 \\
\hline No & 39 & 40.31 & 4.35 \\
\hline
\end{tabular}

The mean value of the positive attitudes of teachers who have taught following the inclusive education model (46.56) is higher than that of teachers who have no experience in this field (40.31). The significance index in this category is $p=0.002<0.05$ and there is therefore a statistically significant difference between the mean values of the two categories, which confirms our third research hypothesis too. 


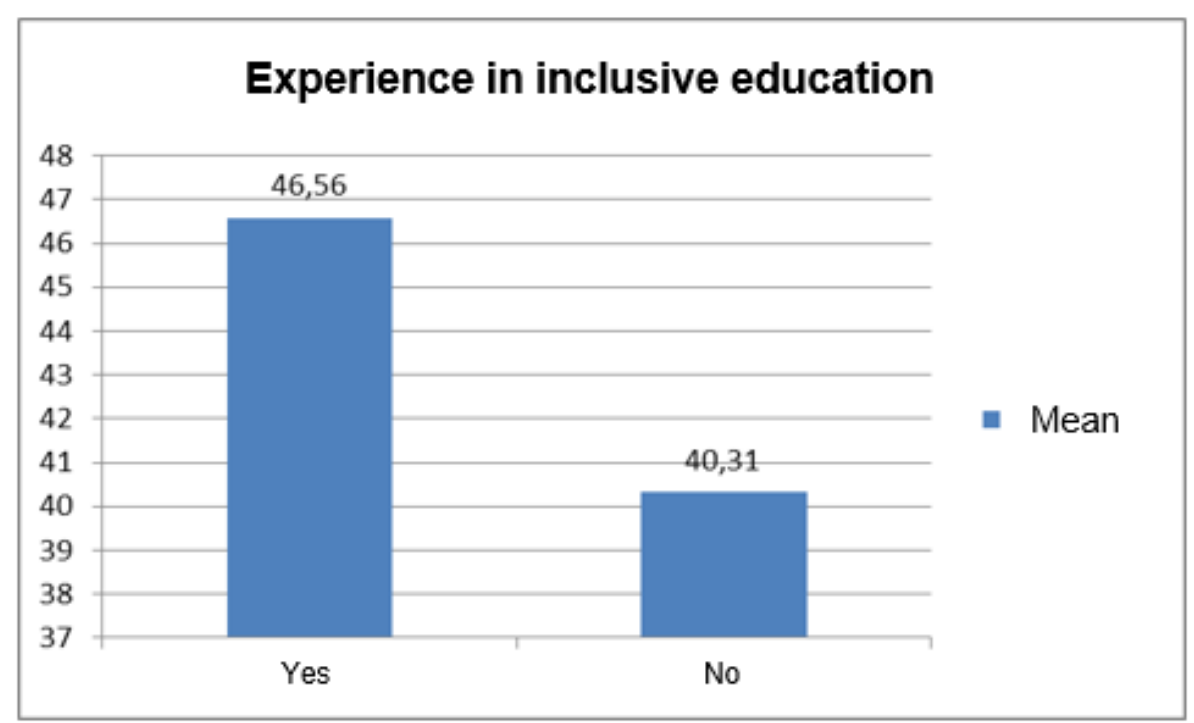

Figure 3: Mean values of the TATIS questionnaire for the variable 'experience in inclusive education'

It is therefore observed that teachers who have taught people with disabilities in the general classroom feel more positively towards inclusive education than their colleagues who do not share a similar experience. Then, through the ANOVA analysis, the mean value for each of the four subcategories of attitudes is presented in detail in order to test more thoroughly the above finding. The 3rd research hypothesis is confirmed since there are statistically significant results. The results of the ANOVA test are presented in Table 15.

Table 15: Mean, standard deviation (SD), F-distribution values and statistical significance level for the interaction between the factors 'subcategories of the TATIS questionnaire' and 'experience in inclusive education'

\begin{tabular}{|c|c|c|c|c|c|}
\hline & & Mean & Standard deviation & F & Sig. \\
\hline \multirow{3}{*}{$\begin{array}{l}\text { Benefits of } \\
\text { inclusive } \\
\text { education }\end{array}$} & Yes & 14.444 & 2.068 & \multirow[t]{3}{*}{9.047} & \multirow[t]{3}{*}{$0.004^{*}$} \\
\hline & No & 11.667 & 2.579 & & \\
\hline & Total & 12.188 & 2.703 & & \\
\hline \multirow{3}{*}{$\begin{array}{l}\text { Teachers' } \\
\text { competence } \\
\text { and readiness }\end{array}$} & Yes & 9.000 & 1.000 & \multirow[t]{3}{*}{0.193} & \multirow[t]{3}{*}{0.663} \\
\hline & No & 9.231 & 1.495 & & \\
\hline & Total & 9.188 & 1.409 & & \\
\hline \multirow{3}{*}{$\begin{array}{l}\text { Educational } \\
\text { material and } \\
\text { infrastructure }\end{array}$} & Yes & 8.333 & 1.658 & \multirow[t]{3}{*}{0.152} & \multirow[t]{3}{*}{0.698} \\
\hline & No & 8.051 & 2.012 & & \\
\hline & Total & 8.104 & 1.938 & & \\
\hline \multirow{3}{*}{$\begin{array}{l}\text { Potential of } \\
\text { students to be } \\
\text { included }\end{array}$} & Yes & 14.778 & 2.167 & \multirow[t]{3}{*}{16.483} & \multirow[t]{3}{*}{$0.0002^{*}$} \\
\hline & No & 11.359 & 2.300 & & \\
\hline & Total & 12.000 & 2.626 & & \\
\hline \multirow{3}{*}{ Total Index } & Yes & 46.556 & 3.779 & \multirow[t]{3}{*}{15.772} & \multirow[t]{3}{*}{$0.0002^{*}$} \\
\hline & No & 40.308 & 4.348 & & \\
\hline & Total & 41.479 & 4.877 & & \\
\hline
\end{tabular}


The results show that in the same two subcategories, our result is statistically significant. In the subcategory referring to the benefits of inclusive education $(p=0.004<0.05)$ there is a statistically significant difference in the mean value of the indices, a fact that confirms our hypothesis as the mean value of the positive attitudes of teachers with experience is higher compared to those without experience. This is also the case in the subcategory regarding teachers' views on the potential of students to be included in the general classroom $(p=0.002<0.05)$, which again confirms our research hypothesis. Teachers with experience have a higher positive average compared to those without an extensive teaching experience.

After summarizing the results arising from the testing regarding the teachers' attitudes towards inclusive education processes, it is ascertained that out of the three research hypotheses, two are largely confirmed while the first hypothesis is not confirmed. More specifically, the hypotheses associating the attendance of a training program and the teachers' previous experience with students with disabilities with the development of more positive attitudes towards the adoption of inclusive education programs are confirmed. Teachers' training in special education and their previous positive experiences from teaching students with disabilities are the two most decisive factors for developing positive attitudes towards the adoption of innovative inclusion programs, according to the findings of our research.

\section{Discussion}

The relatively positive trend presented in the views of our sample with regard to the promotion of inclusive education in the Greek education system as a whole is in line with the general positive view of teachers expressed in similar research studies conducted in the past (Lindsay, 2007; Koutrouba, Vamvakari \& Theodoropoulos, 2008). In the analysis carried out by Scruggs and Mastropieri (1996), where data were collected from 28 surveys on teachers' opinions regarding inclusive education, it appears that 2 out of 3 teachers agree with the general philosophy of inclusive education although less than half of them find the idea feasible. Thus, while teachers are positive towards inclusive education, they feel insecure about their skills but also about how it can be implemented in practice in the school environment (Avramidis \& Kalyva, 2007). In forecasting terms, the lack of necessary educational means and support constitutes a factor of professional burnout for most teachers (Kaufhold, Alverez \& Arnold, 2006).

With regard to the teachers' feeling of lack of readiness regarding inclusive education processes that emerged from the results of the present study, it is confirmed that this lack of readiness stems both from the low quality training on disability issues and the limited experience teachers have with students with disabilities, as well as from the fact that when teaching students with disabilities, teachers feel they assume more responsibility and burden (Batsiou, Bebetsos, Panteli \& Antoniou, 2008).

Subsequently, the analysis of the research results showed a negative correlation between teachers' years of service and their positive views towards inclusive education 
and did not confirm our research hypothesis. Our finding is inconsistent with previous research data (Idol, 2006; Wilkins \& Nietfeld, 2004), which showed a positive correlation between teaching experience and the development of positive views by teachers, and does not confirm our 1st research hypothesis. This particular inconsistency between the findings of this study and the majority of the studies is explained by the fact that in the Greek education system, special education teachers with many years of service have not completed studies in special education but all of them come from general education and are therefore not familiar with inclusive education issues.

In addition, it is apparent that training (postgraduate studies - training seminars) is an important factor in order for the teachers to adopt a positive attitude towards inclusive education programs for students with and without disabilities. Our 2nd research hypothesis has been confirmed, and teachers with training have shown a more positive attitude than their colleagues without training regarding the potential of students with disabilities to be included in the general school, and deemed that the promotion of inclusion will help both themselves and the other students in the educational process.

The fact that there is a large number of research studies with similar results confirms the findings of the present study. The participation in trainings on issues related to special education may have a positive impact on teachers' views towards inclusive education (Grskovic \& Trzcinka, 2011). Furthermore, teachers consider their training to be a necessary prerequisite for their participation in inclusive education programs (Anderson, Klassen \& Georgiou, 2007), while they deem that the main obstacle to practical implementation of inclusive education is the lack of training on special education issues (Heiman, 2004).

According to the findings of the present study, a statistically significant result has emerged on the correlation of previous years of service in special education and the perception teachers had regarding the implemented inclusive education programs. In particular, teachers who have taught students with disabilities have shown a more positive attitude towards participation in inclusive education programs than those who had no such experience. This fact confirmed our 3rd research hypothesis regarding the positive correlation between the two factors.

This finding is confirmed by the Wilkins and Nietfeld study (2004), according to which the positive experience that teachers gain from teaching students with disabilities, particularly in the general school, is the strongest predictor in shaping a positive view towards inclusive education. In fact, teachers report that through the experiences they gain from participating in inclusive education programs, they find ways to deal with the difficult situations of school life in general (Olivarez \& Arnold, 2006). Teachers also seem to shape their views according to the cases and situations with students with disabilities they have managed. When teachers have positive experiences and the expected learning outcomes, they acquire a more positive view regarding the effectiveness of inclusive education programs, while where this is not the case and their experience is negative, their view is negatively affected (Drew \& Mackie, 2011). 
Finally, familiarizing themselves with students with disabilities reduces the fears and prejudices that exist towards these students and increases teachers' interest in acquiring knowledge about their teaching. This way, the creation of a positive attitude towards inclusive education is fostered (Mc Gregor \& Campbell, 2001).

\section{Conclusion}

The present study revealed that teachers who had the opportunity to teach students with disabilities develop a more positive attitude towards inclusive education compared to teachers who have no practical involvement in teaching students with disabilities. The teachers' positive attitude seems to be influenced and reinforced by their training and further studies on the education of students with disabilities, as in this way they are given the opportunity to combine theoretical training with practical application in relation to inclusive education (Avramidis \& Norwich, 2002).

In conclusion, there is a gap between theory and practice with regard to inclusive education programs. This gap is perceived by teachers who deal with the various issues that arise on a daily basis. This gives rise to a variety of reservations about the feasibility of such programs. Thus, it turns out that teachers, although they are aware of the benefits that students with disabilities gain from inclusive education and theoretically show a positive attitude towards its implementation, report that they often feel exposed to the problems that arise daily and the lack of appropriate support from the competent bodies. They characteristically point out that theory is far from practice (Anderson, Klassen \& Georgiou, 2007).

\section{Limitations and Suggestions for Further Research}

With regard to the limitations of the study, generalization is not possible as the sample consists of a small number of participants in each region and cannot be considered representative for the whole country. Moreover, the non-participation of the principals and subject teachers (e.g. music and PE teachers) of the school units limits the depiction of the effects which the implementation of inclusive education programs has on all school classes. This study examines specific factors which are related to inclusive education and affect teachers' attitudes without providing the possibility to explore other factors, such as the prevailing school culture.

For future investigation, it is proposed to extend the research to a larger sample as well as to consider more factors that affect teachers' attitudes. At the same time, qualitative data could also be included in future research in order to examine more indepth the factors affecting teachers' views. Both the present and future research studies can contribute to finding ways to successfully implement inclusive education.

\section{Conflict of interest statement}

The authors declare no conflicts of interests. 


\section{About the author}

Dr. Vasileiadis Ilias is a school psychologist. He is a lecturer at the University of Thessaly and the Aristotle University of Thessaloniki. He Participates in research projects. It also designs scientifically proven interventions for social and emotional support of students.

\section{References}

Anderson, C. J., Klassen, R. M., \& Georgiou, G. K. (2007). Inclusion in Australia: What teachers say they need and what school psychologists can offer. School Psychology International, 28(2), 131-147.

Avramidis, E. (2010). Social relationships of pupils with special educational needs in the mainstream primary class: Peer group membership and peer-assessed social behavior. European Journal of Special Needs Education, 25 (4), 413-429.

Avramidis, E., \& Kalyva, E. (2007). The influence of teaching experience and professional development on Greek teachers' attitudes towards inclusion. European journal of special needs education, 22(4), 367-389.

Avramidis, E., \& Norwich, B. (2002). Teachers' attitudes towards integration/inclusion: a review of the literature. European journal of special needs education, 17(2), 129-147.

Avramidis, E., Bayliss, P., \& Burden, R. (2000). Student teachers' attitudes towards the inclusion of children with special educational needs in the ordinary school. Teaching and teacher education, 16(3), 277-293.

Batsiou, S., Bebetsos, E., Panteli, P., \& Antoniou, P. (2008). Attitudes and intention of Greek and Cypriot primary education teachers towards teaching pupils with special educational needs in mainstream schools. International Journal of Inclusive Education, 12(2), 201-219.

Cullen, J. P., Gregory, J. L., \& Noto, L. A. (2010). The teacher attitudes toward inclusion scale (FATIS) technical report. Savannah, Georgia: 33 ${ }^{\text {rd }}$ Eastern Educational Research Association

De Boer, A., Pijl, S. J., \& Minnaert, A. (2011). Regular primary schoolteachers' attitudes towards inclusive education: A review of the literature. International journal of inclusive education, 15(3), 331-353.

De Laat, S., Freriksen, E., \& Vervloed, M. P. (2013). Attitudes of children and adolescents toward persons who are deaf, blind, paralyzed or intellectually disabled. Research in developmental disabilities, 34(2), 855-863.

Drew, V., \& Mackie, L. (2011). Extending the constructs of active learning: implications for teachers' pedagogy and practice. Curriculum Journal, 22(4), 451-467.

Grskovic, J. A., \& Trzcinka, S. M. (2011). Essential standards for preparing secondary content teachers to effectively teach students with mild disabilities in included settings. American Secondary Education, 94-106. 
Heiman, T. (2004). Teachers Coping with Changes: Including Students with Disabilities in Mainstream Classes: An International View. International journal of special education, 19(2), 91-103.

Idol, L. (2006). Toward inclusion of special education students in general education: A program evaluation of eight schools. Remedial and Special education, 27(2), 77-94.

Kalyva, E., Gojkovic, D., \& Tsakiris, V. (2007). Serbian Teachers' Attitudes towards Inclusion. International Journal of Special Education, 22(3), 31-36.

Kaufhold, J. A., Alverez, V. G., \& Arnold, M. (2006). Lack of School Supplies, Materials and Resources as an Elementary Cause of Frustration and Burnout in South Texas Special Education Teachers. Journal of Instructional Psychology, 33(3).

Koutrouba, K., Vamvakari, M., \& Theodoropoulos, H. (2008). SEN students' inclusion in Greece: factors influencing Greek teachers' stance. European Journal of Special Needs Education, 23(4), 413-421.

Lifshitz, H., Glaubman, R., \& Issawi, R. (2004). Attitudes towards inclusion: The case of Israeli and Palestinian regular and special education teachers. European Journal of Special Needs Education, 19(2), 171-190.

Lindsay, G. (2007). Educational psychology and the effectiveness of inclusive education/mainstreaming. British journal of educational psychology, 77(1), 1-24.

Mc Gregor, E., \& Campbell, E. (2001). The attitudes of teachers in Scotland to the integration of children with autism into mainstream schools. Autism: the international journal of research and practice, 5(2), 189-207.

Olivarez, M. M., \& Arnold, M. (2006). Personal and Demographic Characteristics of Retained Teachers of Special Education. Education, 126(4), 702-710.

Papadopoulou, D., Kokaridas, D., Papanikolaou, Z., \& Patsiaouras, A. (2004). Attitudes of Greek Physical Education Teachers toward Inclusion of Students with Disabilities. International Journal of Special Education, 19(2), 104-111.

Scruggs, T. E., \& Mastropieri, M. A. (1996). Teacher perceptions of mainstreaming/inclusion, 1958-1995: A research synthesis. Exceptional children, 63(1), 59-74.

Vasileiadis, I., \& Doikou-Avlidou, M. (2018). Enhancing social interaction of pupils with intellectual disabilities with their general education peers: the outcomes of an intervention programme. Journal of Research in Special Educational Needs, 18(4), 267277. doi.org/10.1111/1471-3802.12410

Waldron, N. L., McLeskey, J., \& Pacchiano, D. (1999). Giving teachers a voice: Teachers' perspectives regarding elementary inclusive school programs (ISP). Teacher Education and Special Education, 22(3), 141-153.

Wilkins, T., \& Nietfeld, J. L. (2004). The effect of a school-wide inclusion training programme upon teachers' attitudes about inclusion. Journal of Research in Special Educational Needs, 4(3), 115-121.

Zoniou-Sideri, A., \& Vlachou, A. (2006). Greek teachers' belief systems about disability and inclusive education. International journal of inclusive education, 10(4-5), 379-394. 
Vasileiadis Ilias, Koutras Spyros, Dimitriadou Ioanna

THE PERCEPTIONS OF PRIMARY EDUCATION TEACHERS

ABOUT INCLUSIVE EDUCATION IN THE GREEK EDUCATIONAL SYSTEM

Creative Commons licensing terms

Author(s) will retain the copyright of their published articles agreeing that a Creative Commons Attribution 4.0 International License (CC BY 4.0 ) terms will be applied to their work. Under the terms of this license, no permission is required from the author(s) or publisher for members of the community to copy, distribute, transmit or adapt the article content, providing a proper, prominent and unambiguous attribution to the authors in a manner that makes clear that the materials are being reused under permission of a Creative Commons License. Views, opinions and conclusions expressed in this research article are views, opinions and conclusions of the author(s). Open Access Publishing Group and European Journal of Education Studies shall not be responsible or answerable for any loss, damage or liability caused in relation to/arising out of conflicts of interest, copyright violations and inappropriate or inaccurate use of any kind content related or integrated into the research work. All the published works are meeting the Open Access Publishing requirements and can be freely accessed, shared, modified, distributed and used in educational, commercial and non-commercial purposes under a Creative Commons Attribution 4.0 International License (CC BY 4.0). 